\title{
Chlorine as a primary radical: evaluation of methods to understand its role in initiation of oxidative cycles
}

\author{
C. J. Young ${ }^{1,2, *}$, R. A. Washenfelder ${ }^{1,2}$, P. M. Edwards ${ }^{1,2}$, D. D. Parrish ${ }^{2}$, J. B. Gilman ${ }^{1,2}$, W. C. Kuster ${ }^{2}$, \\ L. H. Mielke ${ }^{3, * *}$, H. D. Osthoff ${ }^{3}$, C. Tsai ${ }^{4}$, O. Pikelnaya ${ }^{4}$, J. Stutz ${ }^{4}$, P. R. Veres ${ }^{1,2}$, J. M. Roberts ${ }^{2}$, S. Griffith ${ }^{5}$, \\ S. Dusanter ${ }^{5,6}$, P. S. Stevens ${ }^{5}$, J. Flynn ${ }^{7}$, N. Grossberg ${ }^{7}$, B. Lefer ${ }^{7}$, J. S. Holloway ${ }^{1,2}$, J. Peischl ${ }^{1,2}$, T. B. Ryerson ${ }^{2}$, \\ E. L. Atlas ${ }^{8}$, D. R. Blake ${ }^{9}$, and S. S. Brown ${ }^{2}$ \\ ${ }^{1}$ Cooperative Institute for Research in Environmental Sciences, University of Colorado, Boulder, CO, USA \\ ${ }^{2}$ Chemical Sciences Division, Earth System Research Laboratory, National Oceanic and Atmospheric Administration, \\ Boulder, CO, USA \\ ${ }^{3}$ Department of Chemistry, University of Calgary, Calgary, AB, Canada \\ ${ }^{4}$ Department of Atmospheric and Oceanic Sciences, University of California, Los Angeles, CA, USA \\ ${ }^{5}$ School of Public and Environmental Affairs, Indiana University, Bloomington, IN, USA \\ ${ }^{6}$ Mines Douai, CE, 59508, Douai, France \\ ${ }^{7}$ Department of Earth and Atmospheric Sciences, University of Houston, Houston, TX, USA \\ ${ }^{8}$ Rosenstiel School of Marine and Atmospheric Science, University of Miami, Miami, FL, USA \\ ${ }^{9}$ Department of Chemistry, University of California Irvine, Irvine, CA, USA \\ *now at: Department of Chemistry, Memorial University, St. John's, NL, Canada \\ ** now at: School of Public and Environmental Affairs, Indiana University, Bloomington, IN, USA
}

Correspondence to: C. J. Young (cora.young@mun.ca)

Received: 27 March 2013 - Published in Atmos. Chem. Phys. Discuss.: 23 May 2013

Revised: 18 February 2014 - Accepted: 19 February 2014 - Published: 7 April 2014

\begin{abstract}
The role of chlorine atoms $(\mathrm{Cl})$ in atmospheric oxidation has been traditionally thought to be limited to the marine boundary layer, where they are produced through heterogeneous reactions involving sea salt. However, recent observation of photolytic $\mathrm{Cl}$ precursors $\left(\mathrm{ClNO}_{2}\right.$ and $\left.\mathrm{Cl}_{2}\right)$ formed from anthropogenic pollution has expanded the potential importance of $\mathrm{Cl}$ to include coastal and continental urban areas. Measurements of $\mathrm{ClNO}_{2}$ in Los Angeles during CalNex (California Nexus - Research at the Nexus of Air Quality and Climate Change) showed it to be an important primary (first generation) radical source. Evolution of ratios of volatile organic compounds (VOCs) has been proposed as a method to quantify $\mathrm{Cl}$ oxidation, but we find no evidence from this approach for a significant role of $\mathrm{Cl}$ oxidation in Los Angeles. We use a box model with the Master Chemical Mechanism (MCM v3.2) chemistry scheme, constrained by observations in Los Angeles, to examine the $\mathrm{Cl}$ sensitivity of commonly used VOC ratios as a function of $\mathrm{NO}_{\mathrm{x}}$ and secondary radical production. Model results indicate VOC tracer
\end{abstract}

ratios could not detect the influence of $\mathrm{Cl}$ unless the ratio of $[\mathrm{OH}]$ to $[\mathrm{Cl}]$ was less than 200 for at least a day. However, the model results also show that secondary (second generation) $\mathrm{OH}$ production resulting from $\mathrm{Cl}$ oxidation of VOCs is strongly influenced by $\mathrm{NO}_{\mathrm{x}}$, and that this effect obscures the importance of $\mathrm{Cl}$ as a primary oxidant. Calculated concentrations of $\mathrm{Cl}$ showed a maximum in mid-morning due to a photolytic source from $\mathrm{ClNO}_{2}$ and loss primarily to reactions with VOCs. The $[\mathrm{OH}]$ to $[\mathrm{Cl}]$ ratio was below 200 for approximately $3 \mathrm{~h}$ in the morning, but $\mathrm{Cl}$ oxidation was not evident from the measured ratios of VOCs. Instead, model simulations show that secondary OH production causes VOC ratio evolution to follow that expected for $\mathrm{OH}$ oxidation, despite the significant input of primary $\mathrm{Cl}$ from $\mathrm{ClNO}_{2}$ photolysis in the morning. Even though $\mathrm{OH}$ is by far the dominant oxidant in Los Angeles, $\mathrm{Cl}$ atoms do play an important role in photochemistry there, constituting $9 \%$ of the primary radical source. Furthermore, $\mathrm{Cl}-\mathrm{VOC}$ reactivity differs from that of $\mathrm{OH}$, being more than an order of magnitude larger and 
dominated by VOCs, such as alkanes, that are less reactive toward $\mathrm{OH}$. Primary $\mathrm{Cl}$ is also slightly more effective as a radical source than primary $\mathrm{OH}$ due to its greater propensity to initiate radical propagation chains via VOC reactions relative to chain termination via reaction with nitrogen oxides.

\section{Introduction}

Chlorine atoms $(\mathrm{Cl})$, even if present in the troposphere in small concentrations, can have a significant effect on tropospheric oxidation and can impact the production of ozone in urban environments (Chang and Allen, 2006; Knipping and Dabdub, 2003). Atomic chlorine is extremely reactive towards volatile organic compounds (VOCs), with rate coefficients that are, with few exceptions, at least an order of magnitude larger than those of hydroxyl radicals $(\mathrm{OH})$. In addition, $\mathrm{Cl}$ reacts rapidly with some compounds, such as alkanes, with which $\mathrm{OH}$ is relatively unreactive. Historically, $\mathrm{Cl}$ was thought to be produced primarily from heterogeneous reaction cycles involving sea salt (Keene et al., 1999; Knipping et al., 2000; Erickson et al., 1999) and, consequently, the importance of $\mathrm{Cl}$ to atmospheric oxidation was believed to be limited to the marine boundary layer and coastal areas. Recent measurements of anthropogenically derived photolabile $\mathrm{Cl}$ precursors $\left(\mathrm{ClNO}_{2}\right.$ and $\left.\mathrm{Cl}_{2}\right)$ identify a mechanism for anthropogenic pollution to contribute to production of $\mathrm{Cl}$ (Osthoff et al., 2008; Riedel et al., 2012; Lawler et al., 2009, 2011). The detection of these species in mid-continental areas has expanded the potential impact of $\mathrm{Cl}$ to tropospheric oxidation chemistry (Thornton et al., 2010; Mielke et al., 2011).

Indirect methods must be used to estimate the importance of $\mathrm{Cl}$ in tropospheric photochemistry, since reliable instrumental methods to directly measure $\mathrm{Cl}$ concentrations do not exist. Even in the presence of strong photochemical sources, predicted ambient $\mathrm{Cl}$ concentrations are small ( $<10^{6}$ atoms $\mathrm{cm}^{-3}$; e.g., Riedel et al., 2012). Average concentrations of $\mathrm{Cl}$ on a near-global scale have been inferred using isotope ratios of methane (Allan et al., 2001, 2007; Platt et al., 2004) and the removal rate of tetrachloroethylene (Singh et al., 1996). The spatially and temporally averaged (i.e., hemispheric to global scale over months to years) concentrations in the marine boundary layer were estimated to be on the order of $10^{3}$ atoms $\mathrm{cm}^{-3}$ (Allan et al., 2001; Singh et al., 1996). On local and regional scales, several indirect methods have been used to estimate the concentration of $\mathrm{Cl}$ or its contribution to tropospheric oxidation. First, measurements of $\mathrm{Cl}$ precursors, including $\mathrm{HOCl}, \mathrm{ClO}, \mathrm{Cl}_{2}$, and $\mathrm{ClNO}_{2}$, enable estimates of the importance of $\mathrm{Cl}$ (Osthoff et al., 2008; Riedel et al., 2012; Lawler et al., 2011; Stutz et al., 2002). Second, products of addition reactions of $\mathrm{Cl}$ to unsaturated VOCs, such as the chlorinated product 1-chloro3-methyl-3-butene-2-one (CMBO) from the addition of $\mathrm{Cl}$ to

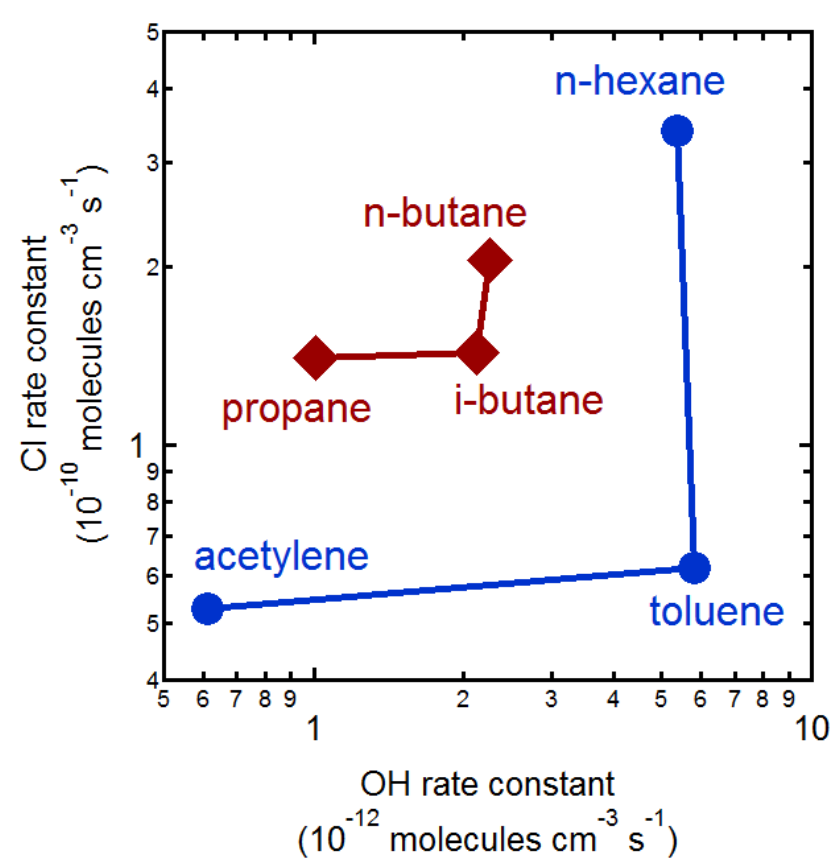

Fig. 1. Rate constants for reaction of $\mathrm{Cl}$ and $\mathrm{OH}$ with VOCs that are used to infer the influence of $\mathrm{Cl}$ oxidation. Rate constants are those used in the model, under conditions described in Table S4.

isoprene, can be used as markers of chlorine oxidation (Nordmeyer et al., 1997). Finally, the most easily applied and commonly used method to infer $\mathrm{Cl}$ importance is examination of VOC tracer ratios. These ratios can determine the relative contributions to oxidation of VOCs by $\mathrm{Cl}$ and $\mathrm{OH}$ (Jobson et al., 1994). This method requires measurement of a set of three VOCs, where two have approximately equal reaction rate coefficients with $\mathrm{OH}$ and two have approximately equal rate coefficients with $\mathrm{Cl}$; two examples are shown in Fig. 1. By tracking the ratios of these compounds in air masses with different ages, it is possible to quantify the relative contribution of $\mathrm{OH}$ and $\mathrm{Cl}$ to oxidation. A key characteristic of the second and third methods is their sensitivity to the total radical concentrations, which result from both primary production (i.e., from photolysis of a precursor) and secondary formation (i.e., from radical propagation reactions). Although there remains considerable uncertainty in the analyses, results of these three indirect methods have been interpreted as indicating that $\mathrm{Cl}$ is an important oxidant in a number of locations, including Houston, Texas (Riemer et al., 2008; Tanaka et al., 2003; Osthoff et al., 2008), the east coast of the United States (Pzsenny et al., 2007), mid-continental North America (Thornton et al., 2010; Mielke et al., 2011), the Arctic (Jobson et al., 1994; Gilman et al., 2010; Ramacher et al., 1999), and Los Angeles, California (Gorham et al., 2010). Average concentrations estimated with these methods range from $10^{2}$ to $10^{5}$ atoms $\mathrm{cm}^{-3}$ (Riemer et al., 2008; Rudolph et al., 1997; Pzsenny et al., 2007; Stutz et al., 2002; Wingenter et al., 1999, 1996, 2005). 
The VOC tracer ratio approach has been among the most commonly used methods to assess the importance of $\mathrm{Cl}$ to tropospheric oxidation. It is sensitive to the relative concentrations of $\mathrm{Cl}$ and $\mathrm{OH}$ radicals. In areas with high nitrogen oxide levels, the use of this method can be complicated by the influence of secondary $\mathrm{OH}$ radical generation through radical propagation cycles, and thus would not necessarily provide an accurate test of primary radical sources. A low $[\mathrm{Cl}]$ to $[\mathrm{OH}]$ ratio may not imply that $\mathrm{Cl}$ is not important as a primary radical source. Effects of this secondary radical generation on $[\mathrm{OH}]$ to $[\mathrm{Cl}]$ ratio interpretation have not been fully evaluated and quantified, though recent field studies suggest a large source of primary $\mathrm{Cl}$ radicals in areas with large $\mathrm{NO}_{\mathrm{x}}$ concentrations through the nighttime formation and daytime photolysis of $\mathrm{ClNO}_{2}$. Furthermore, use of the VOC tracer ratio approach has not been compared with another method to assess the importance of $\mathrm{Cl}$ to tropospheric oxidation. Thus, further examination of this method and its applicability across a range of environments is of interest. In areas where primary radical production is the dominant radical source (e.g., very low or very high $\mathrm{NO}_{\mathrm{x}}$ environments), VOC tracer ratios should be sensitive to the primary inputs. In areas where secondary radicals dominate (e.g., intermediate $\mathrm{NO}_{\mathrm{x}}$ environments such as Los Angeles), VOC ratios are expected to reflect the overall contributions of $\mathrm{Cl}$ and $\mathrm{OH}$ oxidation, but cannot be expected to accurately reflect the relative contribution to the initiation of radial reactions.

Recently, $\mathrm{Cl}$ was shown to be a significant contributor to the primary radical budget in Los Angeles during the CalNex (California Nexus - Research at the Nexus of Air Quality and Climate Change) campaign (Young et al., 2012; Mielke et al., 2013). Using measurements of $\mathrm{ClNO}_{2}$ and other radical precursors, it was demonstrated that $\mathrm{ClNO}_{2}$, as a source of $\mathrm{Cl}$, accounts for $9 \%$ of all primary radicals on average, and for greater than half of ground-level primary radicals during some times in the morning. As such, it might be expected that VOC ratios in this location should show the impact of $\mathrm{Cl}$ oxidation, especially immediately following sunrise; however it has not been possible to identify such an impact. In this paper, we will examine (i) VOC tracer ratios as descriptors of radical chemistry in the Los Angeles (L.A.) Basin during CalNex; (ii) the sensitivity of VOC tracer ratios to $\mathrm{Cl}$ chemistry; (iii) the effect of $\mathrm{NO}_{\mathrm{x}}$ and secondary radical production on VOC tracer ratios; (iv) the impacts of secondary radicals on interpretations of VOC tracer ratios during CalNex; and (v) the mechanisms through which chlorine impacts tropospheric chemistry in Los Angeles. Our ultimate goal is to reconcile the evidence for the significant contribution of $\mathrm{Cl}$ as a primary radical source with the lack of evidence for a direct role of $\mathrm{Cl}$ in $\mathrm{VOC}$ oxidation.

\section{Methods}

\subsection{Measurements}

The CalNex Pasadena ground site was located on the campus of the California Institute of Technology in Pasadena, CA $\left(34.1406^{\circ} \mathrm{N}, 118.1225^{\circ} \mathrm{W}, 236 \mathrm{~m}\right.$ above sea level). The site operated from 15 May to 15 June 2010. Ground site measurements used in this analysis are summarized in Table 1.

Methane was not measured at the Pasadena ground site. In the absence of measurements, we assume a methane mixing ratio of 1.8 ppmv. Measurements of methane from the NOAA WP-3D aircraft during CalNex showed mixing ratios up to 2.1 ppmv over the Los Angeles Basin (Peischl et al., 2013). In addition, many other VOC species are likely present at low levels, but were not included in this study.

The NOAA WP-3D research aircraft flew 20 flights in and around the L.A. Basin from 30 April through 22 June; VOCs were measured in whole air samples (Colman et al., 2001), periodically filled during all flights. In addition, the R/V Atlantis cruised along the coast and within the harbors of California from May 14 through June 8; a subset of VOCs were measured by an on board instrument. Ryerson et al. (2013) give details of these flights and cruise and the related measurements.

\subsection{Reactivity calculation}

The reactivities of $\mathrm{OH}$ and $\mathrm{Cl}$ with other species (i.e., reactivity $\left.\mathrm{Cl} / \mathrm{OH}+\mathrm{X}=k_{\mathrm{OH} / \mathrm{Cl}+\mathrm{X}} \times[\mathrm{X}]\right)$ in the ambient atmosphere were calculated using averaged diurnal cycle concentrations of $\mathrm{ClNO}_{2}, \mathrm{HONO}, \mathrm{OH}, \mathrm{HO}_{2}, \mathrm{O}_{3}, \mathrm{NO}, \mathrm{NO}_{2}$, $\mathrm{CO}$, acids, and speciated VOCs. The acid measurements included $\mathrm{HONO}, \mathrm{HNO}_{3}, \mathrm{HCl}$, and $\mathrm{HCOOH}$ (Young et al., 2012; Veres et al., 2011). The VOC measurements included $\mathrm{C}_{2}-\mathrm{C}_{6}$ and $\mathrm{C}_{9}-\mathrm{C}_{11}$ alkanes, $\mathrm{C}_{2}-\mathrm{C}_{5}$ alkenes, ethyne, $\mathrm{C}_{1}-$ $\mathrm{C}_{3}$ alcohols, $\mathrm{C}_{6}-\mathrm{C}_{9}$ aromatics, $\mathrm{C}_{1}-\mathrm{C}_{4}$ aldehydes, glyoxal, $\mathrm{C}_{3}-\mathrm{C}_{4}$ ketones, 2,3-butadione, acetonitrile, bromoform, isoprene, methyl vinyl ketone (MVK), methacrolein, $\alpha$ - and $\beta$-pinene and limonene (Washenfelder et al., 2011; Wong et al., 2011; Gilman et al., 2010). Kinetic parameters were taken from preferred or recommended values where possible (Atkinson et al., 2006, 2007; Sander et al., 2011). Rate constants were not available for $\mathrm{Cl}$ reaction with decane and a number of alkyl benzenes, as well as the reaction of $\mathrm{OH}$ with 1-ethyl-2-methylbenzene. For these reactions, rate constants for similar species were used. A complete list of included species, reaction rate constants, and references are included as Table $\mathrm{S} 1$ in the Supplement.

\subsection{Modeling}

We used a subset of the Master Chemical Mechanism (MCM) version 3.2 (Jenkin et al., 1997, 2003; Saunders et al., 2003) in the AtChem box model version 1.5 (Boronska et al., 2013) to study (1) the impact of $[\mathrm{Cl}]$ to $[\mathrm{OH}]$ ratio on 
Table 1. Relevant measurements acquired during CalNex 2010.

\begin{tabular}{|c|c|c|c|c|}
\hline Species & Technique & Uncertainty $(1 \sigma)^{*}$ & Frequency & Reference \\
\hline $\mathrm{O}_{3}$ & UV differential absorption & $\pm(0.4 \mathrm{ppbv}+4 \%)$ & $1 \mathrm{~min}$ & Thermo Scientific model 49c \\
\hline $\mathrm{OH}$ & $\begin{array}{l}\text { Laser induced fluorescence } \\
\text { (LIF-FAGE) }\end{array}$ & $\pm\left(4 \times 10^{5} \mathrm{~cm}^{-3}+18 \%\right)$ & $15 \mathrm{~min}$ & (Dusanter et al., 2009) \\
\hline $\mathrm{HO}_{2}$ & LIF-FAGE & & $15 \mathrm{~min}$ & (Dusanter et al., 2009) \\
\hline $\mathrm{NO}$ & Chemiluminescence & $\pm 4 \%$ & $1 \mathrm{~min}$ & Thermo Scientific model 42i-TL \\
\hline $\mathrm{NO}_{2}$ & $\begin{array}{l}\text { Cavity ringdown } \\
\text { spectroscopy }\end{array}$ & $\pm 3 \%$ & $1 \mathrm{~min}$ & (Washenfelder et al., 2011) \\
\hline HONO & $\begin{array}{l}\text { Incoherent cavity enhanced } \\
\text { absorption spectroscopy } \\
\text { (IBBCEAS) }\end{array}$ & $\pm(52 \mathrm{pptv}+30 \%)$ & $10 \mathrm{~min}$ & (Young et al., 2012) \\
\hline $\mathrm{ClNO}_{2}$ & $\begin{array}{l}\text { Chemical ionization mass } \\
\text { spectrometry (CIMS) with } \\
\text { iodide ionization }\end{array}$ & $\pm 30 \%$ & $30 \mathrm{~s}$ & (Mielke et al., 2011) \\
\hline $\mathrm{CO}$ & Vacuum UV fluorescence & $\pm 5 \%$ & $1 \mathrm{~s}$ & (Gerbig et al., 1999) \\
\hline Gas-phase acids & $\begin{array}{l}\text { Negative-ion proton transfer } \\
\text { reaction CIMS }\end{array}$ & $\pm(30 \mathrm{pptv}+35 \%)$ & $1 \mathrm{~min}$ & (Veres et al., 2011) \\
\hline Speciated VOCs & $\begin{array}{l}\text { Gas chromatography - mass } \\
\text { spectrometry (GC-MS) }\end{array}$ & 5-25\% (hydrocarbons) & $30 \mathrm{~min}$ & (Gilman et al., 2010) \\
\hline Formaldehyde & $\begin{array}{l}\text { Differential optical } \\
\text { absorption spectroscopy } \\
\text { (DOAS) }\end{array}$ & $\begin{array}{l}20-35 \% \text { (oxygenates) } \\
\pm 5 \%\end{array}$ & Variable & (Wong et al., 2011) \\
\hline Glyoxal & IBBCEAS & $\pm(40 \mathrm{pptv}+15 \%)$ & $1 \mathrm{~min}$ & (Washenfelder et al., 2011) \\
\hline Photolysis & $\begin{array}{l}\text { Scanning actinic flux } \\
\text { spectroradiometer (SAFS) }\end{array}$ & $\pm 30 \%$ & $1 \mathrm{~min}$ & (Shetter and Muller, 1999) \\
\hline
\end{tabular}

${ }^{*}$ For uncertainties given as $(x$ pptv $+y \%), x$ represents the precision and $y$ represents the accuracy.

VOC tracer ratios; (2) the impact of $\mathrm{NO}_{\mathrm{x}}$ on VOC tracer ratios; and (3) the evolution of VOC tracer ratios that would be expected under conditions observed at CalNex, assuming no continuing emissions of VOCs into the box. This model contains near-explicit degradation mechanisms and kinetics for gas-phase tropospheric chemistry. The subset used here includes all inorganic reactions and reactions for 18 selected VOCs and their products, as described below. We modified the MCM scheme to include photolysis of $\mathrm{ClNO}_{2}$ to yield $\mathrm{Cl}$. Within MCM v3.2, $\mathrm{Cl}$ kinetics and mechanisms are included only for alkanes. We added $\mathrm{Cl}$ kinetics and degradation mechanisms for methanol, ethanol, isopropanol, formaldehyde, acetone, ethyne, ethene, and toluene (Taatjes et al., 1999; Atkinson et al., 2006; Yamanaka et al., 2007; Kaiser and Wallington, 2010; Zhou et al., 2005; Yarwood et al., 1991), with the reaction rates given in Table S1. Concentrations for all alkanes and alcohols that were measured at the CalNex ground site were explicitly included (ethane, propane, $n$-butane, $i$-butane, $n$-pentane, $i$-pentane, hexane, nonane, decane, undecane, methanol, ethanol, and isopropanol). The chemistry of $\mathrm{Cl}$ with alcohols was included with little modification of the model, because their reactions with $\mathrm{Cl}$ are well characterized and proceed by hydrogen abstraction leading to a radical species that is already explicitly included in the model. Radical yields for reaction of Cl with alcohols were taken from Taatjes et al. (1999) and Yamanaka et al. (2007).

Other classes of compounds have complex reactions with $\mathrm{Cl}$ that are poorly understood. For these other VOCs, a representative mixture was developed to model $\mathrm{Cl}$ chemistry. The compound that was measured in highest concentration was used to represent that compound class and the chemistry and kinetics of reaction with $\mathrm{Cl}$ atoms for that compound were added into the model. Formaldehyde represented aldehydes, acetone represented ketones, ethene represented alkenes (including biogenics), and toluene represented alkyl benzenes. For biogenic VOCs, current knowledge of reactions with $\mathrm{Cl}$ is insufficient for inclusion in the model. Biogenic VOCs accounted for approximately $7 \%$ of total alkenes. Concentrations of all compounds in each class were summed and used to represent the concentration of the representative compound within the model. The chemistry and kinetics of each representative compound were assumed to represent the entire class. Average measured VOC concentrations from just before sunrise (04:30 Pacific Daylight Time, PDT $=$ UTC $7 \mathrm{~h}$ ) were used to initialize the model, with no further emissions included. Conditions for the model can be found in the Supplement.

All model simulations were conducted using data from the Pasadena ground site. The date was constrained to 1 
June 2010 (the midpoint of the campaign), temperature to $290 \mathrm{~K}$, pressure to $2.46 \times 10^{19}$ molecules $\mathrm{cm}^{-3}$, and concentration of water to $4.2 \times 10^{17}$ molecules $\mathrm{cm}^{-3}$ (equivalent to $90 \%$ relative humidity). Photolysis rate constants were calculated by the Tropospheric Ultraviolet and Visible (TUV) Radiation Model included within MCM v3.2. The photolysis rate constant for $\mathrm{ClNO}_{2}$ is not included in the TUV model and, to avoid significant modification of TUV, was parameterized as a linear combination of measured $J_{\mathrm{O}_{3}}$ and $J_{\mathrm{NO}_{2}}$, with $J_{\mathrm{CINO}_{2}}$ derived from measured actinic fluxes and cross sections (Ghosh et al., 2011):

$J_{\mathrm{ClNO}_{2}}=J_{\mathrm{NO}_{2}}(0.0267)+J_{\mathrm{O}_{3}}(3.11)$.

The error in $J_{\mathrm{ClNO}_{2}}$ for this parameterization compared to the direct calculation is less than $30 \%$ for all solar zenith angles. Concentrations of nitrate radicals were fixed to zero, although $\mathrm{NO}_{3}$ oxidation would have little if any influence on the chosen VOCs due to the slow reaction rate coefficients of this radical with alkanes. Model simulations began just before sunrise (05:15 PDT) and continued past the end of the photochemical day (22:00 PDT).

We modeled three different scenarios to explore the role of $\mathrm{Cl}$ concentrations on the evolution of VOC ratios. The first (Condition Set 1) explored the impact of $[\mathrm{OH}]$ to $[\mathrm{Cl}]$ ratios on VOC tracer ratios under conditions of solely primary radical production. A fixed (i.e., time invariant) radical concentration of $5 \times 10^{6}$ molecules $\mathrm{cm}^{-3}$ was used, with relative amounts of $\mathrm{OH}$ and $\mathrm{Cl}$ varying between different model runs to make up this total. Keeping the total number of radicals constant allowed us to explore the effect of $[\mathrm{OH}]$ to $[\mathrm{Cl}]$ ratios, which have been used as a common metric for the influence of $\mathrm{Cl}$ in past studies (Pzsenny et al., 2007). The concentrations of $\mathrm{NO}$ and $\mathrm{NO}_{2}$ were fixed to zero throughout the simulation. The second scenario (Condition Set 2) explored the impact of $\mathrm{NO}_{\mathrm{x}}$ on $\mathrm{VOC}$ tracer ratios with $\mathrm{Cl}$ atoms as the sole primary radicals. Primary production of $\mathrm{Cl}$ as a product of $\mathrm{ClNO}_{2}$ photolysis was included, while primary sources of $\mathrm{OH}$ (i.e., HONO photolysis and reaction of $\mathrm{O}\left({ }^{1} \mathrm{D}\right)$ with water) were eliminated by fixing the initial HONO concentration at zero and setting the $\mathrm{O}\left({ }^{1} \mathrm{D}\right)+\mathrm{H}_{2} \mathrm{O}$ reaction to produce no products in the model. Initial concentrations of $\mathrm{NO}_{2}$ were fixed within a given simulation, but were changed between simulations. In the third scenario (Condition Set 3), two different radical conditions were simulated in order to more fully explore the effect of the $\mathrm{NO}_{\mathrm{x}}$ concentrations observed at CalNex. In the first (3a), $\mathrm{OH}$ was formed from reaction of $\mathrm{O}\left({ }^{1} \mathrm{D}\right)$ with water and photolysis of nighttime accumulated $\mathrm{HONO}$, while $\mathrm{Cl}$ was formed from photolysis of $\mathrm{ClNO}_{2}$. In the second (3b), reaction of $\mathrm{O}\left({ }^{1} \mathrm{D}\right)$ plus water and $\mathrm{HONO}$ photolysis was unchanged, but photolysis of $\mathrm{ClNO}_{2}$ was prescribed to produce $\mathrm{OH}$ instead of $\mathrm{Cl}$ in the model. Thus, simulation $3 \mathrm{~b}$ maintained the same production rate and temporal distribution of primary radicals and changed only the identity of the radical between $\mathrm{OH}$ and $\mathrm{Cl}$. In both cases,
$\mathrm{NO}_{2}$ was fixed at $18 \mathrm{ppbv}$, comparable to the mixing ratio observed in the morning during CalNex (Fig. S1).

\section{Results and discussion}

\subsection{VOC tracer ratios from California}

Ratios of VOC tracers are commonly used to assess the relative importance of VOC oxidation by $\mathrm{Cl}$ and $\mathrm{OH}$. Tracer ratios of VOCs are affected by mixing of air parcels that have different emission and photochemical histories. Nevertheless, even in the presence of such mixing, each ratio generally does provide a reasonably accurate determination of the degree of photochemical processing of the more reactive VOC included in the ratio (Parrish et al., 2007) provided the difference between the rate constants of the two VOCs composing the ratio is relatively large.

Here we examine VOC tracer ratios measured during the campaign for evidence of VOC oxidation by $\mathrm{Cl}$ atoms. The set of compounds that includes $i$-butane, $n$-butane, and propane has been used for this purpose (e.g., Jobson et al., 1994) including in Los Angeles (Gorham et al., 2010). The red points in Fig. 1 illustrate the $\mathrm{Cl}$ and $\mathrm{OH}$ rate coefficients for this set of alkanes, which is long-lived with respect to reaction with $\mathrm{OH}$. A faster-reacting set of VOCs, toluene, acetylene, and $n$-hexane (blue points in Fig. 1), yield more sensitive indicator ratios. Rudolph et al. (1997) used a similar set of VOCs with benzene replacing acetylene. Here we will examine both of these two sets of tracer ratios. All four ratios in the two sets of VOC tracer ratios were calculated from measurements made both at the Pasadena ground site and from the WP-3D aircraft on all flights within or offshore of California. This latter data set is concentrated in the Los Angeles Basin, but does include much of the state of California. These ratios are included in Fig. 2 along with lines indicating the slopes expected if solely $\mathrm{OH}$ or $\mathrm{Cl}$ oxidation were occurring. These lines were calculated so that they intersect at the average emission ratios of the respective VOCs based on those reported by Borbon et al. (2013).

In Fig. 2 there is little systematic change in either the average ratio of $[i$-butane $] /[n$-butane $]$ relative to the change in $[i$ butane] / [propane] or the [toluene] / $n$-hexane] ratio relative to the change in [toluene]/[propane], indicating the VOCs are predominantly oxidized by $\mathrm{OH}$. The relatively small systematic change in the average ratios is not in the direction that indicates a significant contribution from $\mathrm{Cl}$ atom oxidation; rather it is in the opposite direction for both sets of VOC tracer ratios. There is significant scatter in the data, suggesting that there is substantial variability in the measured VOC ratios that is unrelated to oxidation, arising from variability in VOC ratios in emissions from different sources and from experimental imprecision, which dominates at lower VOC ratios (see further discussion below). The aircraft data shown in Fig. 2 include all measurements regardless of altitude or 
A

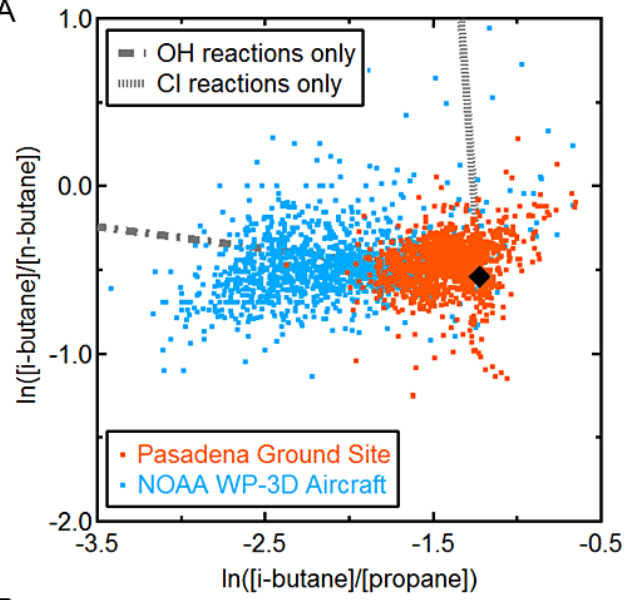

B

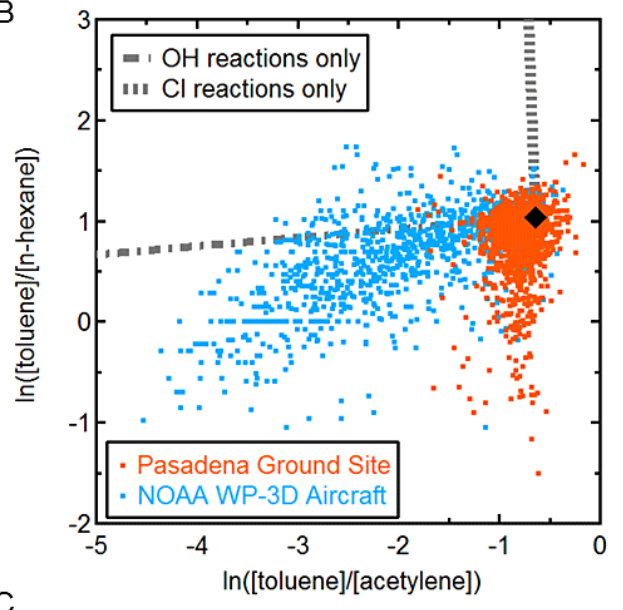

C

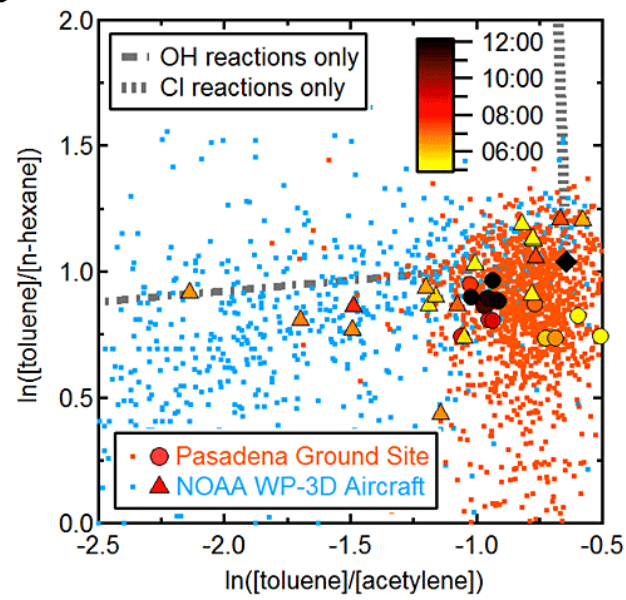

Fig. 2. VOC tracer ratios measured at the Pasadena CalNex ground site and on the WP-3D aircraft. (A, B) All data for all days for the entire campaign. The lines indicate expected tracer ratio evolution for $\mathrm{OH}$ and $\mathrm{Cl}$ oxidation starting from Los Angeles Basin emission ratios (black diamonds) determined by Borbon et al. (2013). (C) Data from (B) on expanded axes with data collected from 05:00 to 13:00 PDT on 3 June 2010 at the ground site and from the aircraft at altitudes below $1000 \mathrm{~m}$ identified by large symbols, color-coded by time of day. location within or offshore of California. Limiting data to a particular region (e.g., the Los Angeles Basin or the Central Valley) or to a specific altitude range (such as within the planetary boundary layer) did not reveal any significant differences in the systematic changes of the VOC ratios. In addition, $i$-butane, $n$-butane, and propane were measured on the R/V Atlantis (Ryerson et al., 2013) during its cruise along the coast and within the harbors of California. Compared to the data in Fig. 2a, the ratios calculated from these data (not shown) exhibited greater scatter (presumably due to measurements made in close proximity to many different large emission sources), but the average systematic trends were not significantly different.

We also specifically examined VOC tracer ratios on the day of 3 June 2010 (large, color-coded symbols in Fig. 2c), for which the preceding night had the highest concentration of $\mathrm{ClNO}_{2}$ (nocturnal maximum of $3.5 \mathrm{ppbv}$ ) observed at Pasadena during the campaign; hence that day may provide the best opportunity to observe the influence of $\mathrm{Cl}$ oxidation at local scales. During the morning (07:00-11:00 PDT), when $\mathrm{Cl}$ concentrations resulting from photolysis of $\mathrm{ClNO}_{2}$ would be highest, the data from both Pasadena and the aircraft are scattered along, but generally below, the $\mathrm{OH}$ oxidation line, with no evidence for $\mathrm{Cl}$ oxidation. These data also indicate $\mathrm{OH}$ as the dominant oxidant.

The evolution of the relative mixing ratios of the six VOCs in Fig. 2 provides no evidence for the influence of $\mathrm{Cl}$ oxidation in the total data or the data for the individual day selected for maximum nocturnal $\mathrm{ClNO}_{2}$ concentration, despite the demonstrably large input of $\mathrm{Cl}$ radicals from $\mathrm{ClNO}_{2}$ photolysis. Similar conclusions are reached in examination of various subsets of these data, and the shipborne measurements of $i$-butane, $n$-butane, and propane. Young et al. (2012) found $\mathrm{Cl}$ formation from photolysis of $\mathrm{ClNO}_{2}$ accounted for approximately $9 \%$ of primary radicals formed during each day at the ground, where primary radical sources were assumed to include photolysis of nighttime accumulated $\mathrm{HONO}, \mathrm{O}_{3}$ photolysis and the subsequent reaction of $\mathrm{O}\left({ }^{1} \mathrm{D}\right)$ with water vapor, and photolysis of $\mathrm{ClNO}_{2}$. In the same study, it was observed that photolysis of $\mathrm{ClNO}_{2}$ accounted for approximately half of primary radicals formed between 06:00 and 12:00 PDT. By contrast, all data shown in Fig. 2 (and considered in other analyses not shown) suggest that $\mathrm{Cl}$ was not important for direct VOC oxidation at either the Pasadena location or throughout California during the CalNex time period. Examination of this apparent discrepancy between the quantification of the primary radical sources and evolution of VOC tracer ratios is needed to understand the importance of $\mathrm{Cl}$ to VOC oxidation and ozone formation in Los Angeles. The following sections investigate the evolution of the VOC tracer relationships within the box-model calculations described in Sect. 2.3 


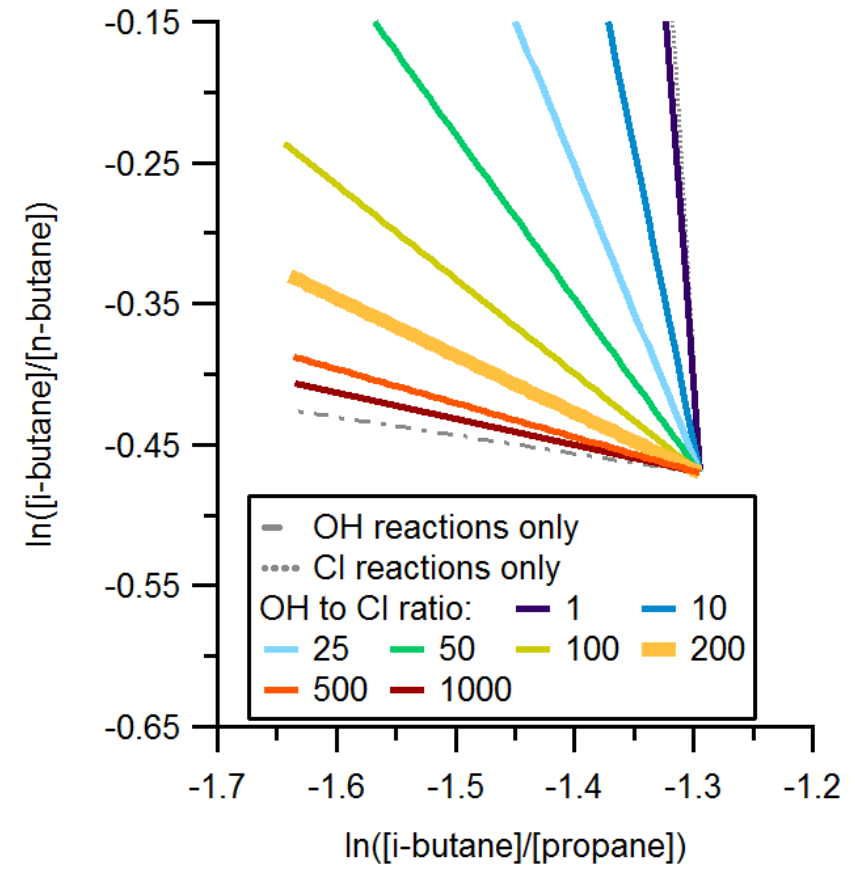

Fig. 3. Evolution of one set of VOC tracer ratios ( $i$-butane, $n$ butane, and propane) under different ratios of $[\mathrm{OH}]$ to $[\mathrm{Cl}]$ (Condition Set 1) in the absence of $\mathrm{NO}_{\mathrm{x}}$. The total radical concentration was held at $5 \times 10^{6}$ molecules $\mathrm{cm}^{-3}$ and photochemical processing was allowed to proceed for $17 \mathrm{~h}$.

\subsection{Sensitivity of VOC tracer ratios to $\mathrm{Cl}$ radicals}

We used the MCM v3.2 chemistry scheme with simplified Los Angeles conditions (described above as Condition Set 1) to assess the sensitivity of VOC tracer ratios to the presence of $\mathrm{Cl}$. Figure 3 depicts the VOC tracer ratio evolution expected for different $\mathrm{OH}$ to $\mathrm{Cl}$ ratios for a constant radical concentration of $5 \times 10^{6}$ molecules $\mathrm{cm}^{-3}$. A ratio of 1000 is observationally indistinguishable from $\mathrm{OH}$ reactions only, while a ratio of 1 is observationally indistinguishable from $\mathrm{Cl}$ reactions only. The sensitivity of VOC tracer ratios to the presence of $\mathrm{Cl}$ will depend on $\mathrm{VOC}$ tracer ratio measurement precision and variability. Based on the scatter in the available data (see Fig. 2a), the maximum $\mathrm{OH}$ to $\mathrm{Cl}$ ratio allowing for detection of $\mathrm{Cl}$ oxidation using these VOC tracer ratios is estimated as approximately 200. Assuming scatter as observed in Fig. 2a, a daytime average concentration of $\mathrm{OH}$ of $2 \times 10^{6}$ molecules $\mathrm{cm}^{-3}$, and an ideal case of an isolated air parcel with no injection of fresh VOC emissions, this $\mathrm{OH}$ to $\mathrm{Cl}$ ratio would have to be sustained for more than 1 day for the $\mathrm{Cl}$ reactions signature to be detectable. With a fasterreacting set of VOC tracers, this time period would decrease. If $\mathrm{Cl}$ concentrations are elevated over only a short time period, the ratio of $\mathrm{OH}$ to $\mathrm{Cl}$ required for detection of the $\mathrm{Cl}$ influence would be higher.

\subsection{Impact of $\mathrm{NO}_{\mathrm{x}}$ and secondary radicals on VOC tracer ratios}

A very important characteristic of the photochemistry of the urban atmosphere is the formation of secondary radicals through chain reaction mechanisms. An $\mathrm{OH}$ or $\mathrm{Cl}$ radical initiates the VOC oxidation process by directly reacting with the VOC, and (through multiple steps) forming a peroxy radical of the form $\mathrm{HO}_{2}$ or $\mathrm{RO}_{2}$, where $\mathrm{R}$ represents an organic group formed from part of the VOC reactant. In the absence of $\mathrm{NO}_{\mathrm{x}}$, peroxy radicals react predominantly via self-reactions that lead to radical termination:

$\mathrm{RO}_{2}+\mathrm{HO}_{2} \rightarrow \mathrm{ROOH}+\mathrm{O}_{2}$,

$\mathrm{RO}_{2}+\mathrm{R}^{\prime} \mathrm{O}_{2} \rightarrow \mathrm{ROH}+\mathrm{R}^{\prime \prime} \mathrm{CO}$,

Although $\mathrm{RO}_{2}$ radicals can self-react leading to radical propagation, this is not their dominant fate. Conversely, in high$\mathrm{NO}_{\mathrm{x}}$ environments, such as Los Angeles, the input of a single radical can lead to radical propagation and formation of many secondary radicals:

$\mathrm{RO}_{2}+\mathrm{NO} \rightarrow \mathrm{RO}+\mathrm{NO}_{2}$,
$\mathrm{RO}+\mathrm{O}_{2} \rightarrow \mathrm{R}^{\prime} \mathrm{CO}+\mathrm{HO}_{2}$,
$\mathrm{HO}_{2}+\mathrm{NO} \rightarrow \mathrm{OH}+\mathrm{NO}_{2}$.

The cycle described by Reactions (R4)-(R6) can continue with the radical produced in Reaction (R6) leading to production of another $\mathrm{RO}_{2}$ and further secondary radicals. In addition, R'CO formed from Reaction (R5) is typically an aldehyde or ketone, which can photolyze or react with $\mathrm{OH}$ or $\mathrm{Cl}$, substantially increasing the efficiency of propagation depending on the timescale for photolysis. Two important features of this cycle should be noted. First, initiation of radical propagation through Reaction (R4) requires the presence of $\mathrm{NO}_{\mathrm{x}}$. Second, even if the initial radical is $\mathrm{Cl}$, the secondary radical produced in Reaction (R6) is an $\mathrm{OH}$.

In Pasadena, during CalNex, observed daytime $\mathrm{NO}_{\mathrm{x}}$ ranged from 1.3 to $82 \mathrm{ppbv}$, with a campaign daytime mean of $15.2 \mathrm{ppbv}$. The MCM model was used to explore the role of $\mathrm{NO}_{\mathrm{x}}$ on secondary radical formation and VOC tracer ratios using simplified chemistry representative of conditions observed in Pasadena during CalNex (Condition Set 2). Within the chemistry scheme, concentrations of $\mathrm{NO}_{2}$ were fixed, with initial concentrations of $\mathrm{NO}$ set to zero, to determine the impact of $\mathrm{NO}_{\mathrm{x}}$. The reactions responsible for primary production of $\mathrm{OH}$ were turned off, so that $\mathrm{OH}$ could only be produced through secondary production following primary production of $\mathrm{Cl}$. The impact of $\mathrm{NO}_{2}$ increases on $\mathrm{VOC}$ tracer ratios is shown in Fig. $4 \mathrm{a}$. As $\mathrm{NO}_{2}$ mixing ratios increase from 0 to $2 \mathrm{ppbv}$, the VOC tracer ratios move from the $\mathrm{Cl}$ oxidation line toward the $\mathrm{OH}$ oxidation line, even though there is no primary production of $\mathrm{OH}$ within the system. Figure $4 \mathrm{~b}$ depicts the change in integrated secondary $\mathrm{OH}$ produced from $\mathrm{ClNO}_{2}$ photolysis-initiated chemistry as a function of $\mathrm{NO}_{2}$ mixing ratio. As the fixed $\mathrm{NO}_{2}$ mixing 
ratio increases from 0 to $1.5 \mathrm{ppbv}$, the integrated production of secondary $\mathrm{OH}$ increases, as radical propagation initiated through Reaction (R4) is enhanced. The effect of additional $\mathrm{NO}_{2}$ decreases at higher $\mathrm{NO}_{2}$ mixing ratios. This occurs as a result of the growing importance of the radical sink reaction of $\mathrm{NO}_{2}$ with $\mathrm{OH}$ to form $\mathrm{HNO}_{3}$. As $\mathrm{NO}_{2}$ mixing ratios are further increased, ratios move slightly away from the $\mathrm{OH}$ oxidation line as the importance of $\mathrm{OH}$ radical loss to $\mathrm{HNO}_{3}$ increases. Despite the fact that $\mathrm{Cl}$ is the sole primary radical produced in this simulation, production of secondary $\mathrm{OH}$ radicals in the presence of $\mathrm{NO}_{\mathrm{x}}$ effectively masks the contribution of $\mathrm{Cl}$ as the initiator of the oxidation process.

The chain length for radical propagation may be defined as the instantaneous ratio of the rate of conversion of $\mathrm{HO}_{2}$ to $\mathrm{OH}$ to that of total radical termination. In a separate set of simulations where the $\mathrm{OH}$ reactivity with respect to VOCs was similar to CalNex, the chain length of radical propagation was determined as a function of $\mathrm{NO}_{\mathrm{x}}$. The chain length for radical propagation varied from 1 to 6 , with an initial increase with increasing concentration of $\mathrm{NO}_{\mathrm{x}}$, followed by a decrease with further concentration increase (similar to the trend for secondary radicals in Fig. 4b). This implies that the reaction of a single $\mathrm{Cl}$ atom could lead to the production of 1-6 OH radicals. Radical propagation chain lengths were similar for $\mathrm{Cl}$ and $\mathrm{OH}$.

This simple simulation in Fig. 4 is a qualitative depiction of the influence of $\mathrm{Cl}$ on the time evolution of VOCs. These model results describe a single total VOC concentration. Results are qualitatively similar when total concentrations of VOCs are changed (Fig. S2). The representative VOC mixture used in our model simulations is simplified, with the simplest available compound from many compound classes, which reduces the probability of radical recycling. In particular, reactive biogenics, many of which contain multiple double bonds, were represented in this simulation by ethene. It has been suggested that isoprene may recycle $\mathrm{OH}$ efficiently (Lelieveld et al., 2008; Archibald et al., 2011) and representation of this species by ethene likely underestimates calculated secondary radical production. Additionally, no emissions were included in this simulation, $\mathrm{ClNO}_{2}$ was used as the sole radical source, and there was no mechanism included to form secondary $\mathrm{Cl}$ (see discussion below). Despite these caveats, the model clearly shows that formation of secondary $\mathrm{OH}$ from $\mathrm{Cl}$ oxidation will greatly reduce the apparent contribution of $\mathrm{Cl}$ to $\mathrm{VOC}$ oxidation as inferred from VOC ratios in $\mathrm{NO}_{\mathrm{x}}$-rich regions, even if $\mathrm{Cl}$ is the sole driver initiating the oxidation cycle.

\subsection{Impacts of secondary radical chemistry on VOC tracer ratios in Los Angeles}

We can estimate the concentration of $\mathrm{Cl}$ present during CalNex using measurements averaged over a diurnal cycle and the steady-state approximation, i.e., using $\mathrm{ClNO}_{2}$ photolysis as a source balanced by $\mathrm{Cl}$ loss to oxidation of VOCs
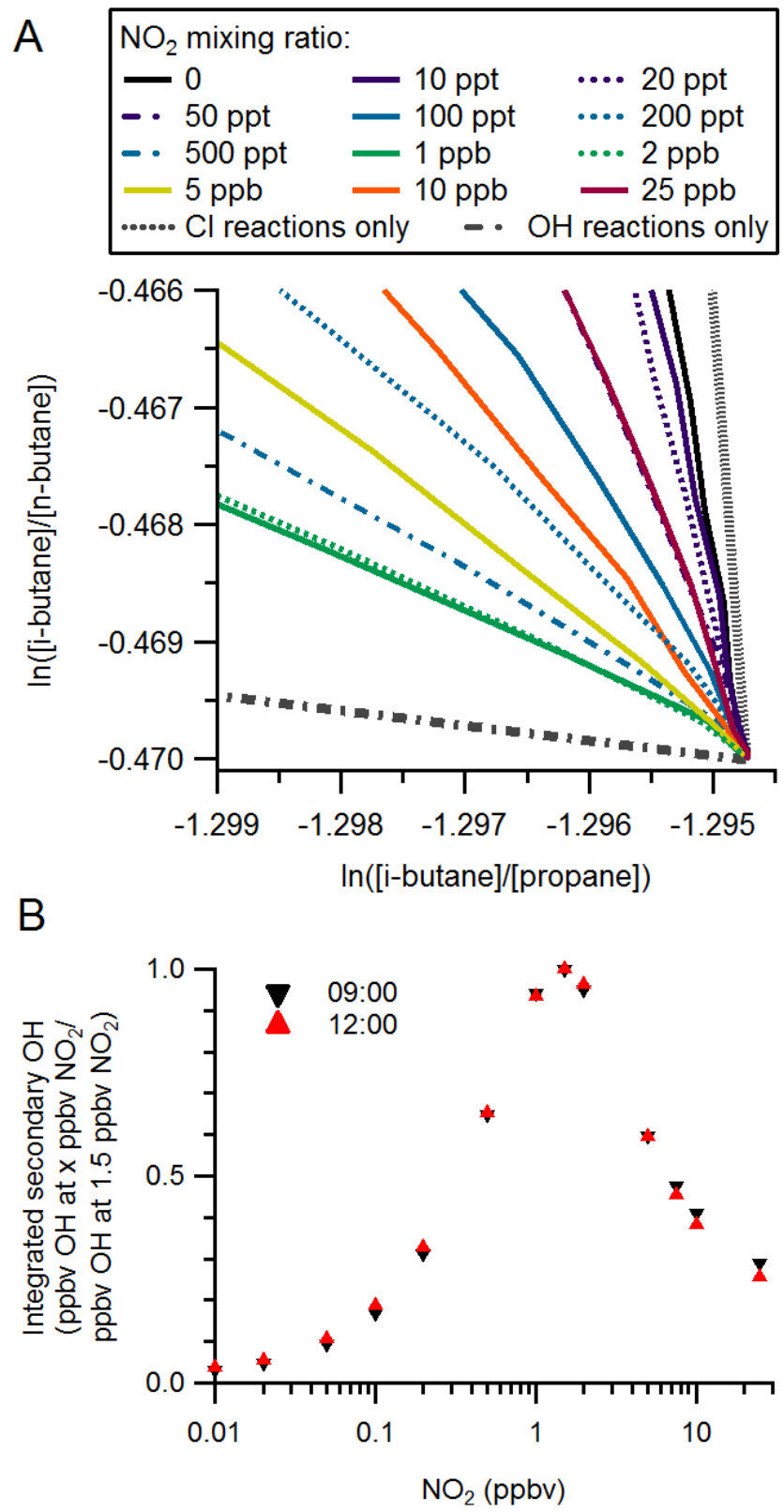

Fig. 4. $\mathrm{MCM}$ calculation results of $\mathrm{ClNO}_{2}$-initiated chemistry with different $\mathrm{NO}_{\mathrm{x}}$ conditions (Condition Set 2): (A) evolution of one set of VOC tracer ratios ( $i$-butane, $n$-butane, and propane), and (B) integrated secondary $\mathrm{OH}$ under varying conditions of $\mathrm{NO}_{2}$. Note that the $x$ and $y$ axis scales in (A) are expanded relative to Fig. 2 to show the influence of $\mathrm{NO}_{2}$ on VOC ratios.

(Fig. 5). Up to this point, we have assumed that photolysis of $\mathrm{ClNO}_{2}$ is the only source of $\mathrm{Cl}$. Measurements aboard $\mathrm{R} / \mathrm{V}$ Atlantis taken off the coast of Los Angeles during Cal$\mathrm{Nex}$ indicate that other primary sources of $\mathrm{Cl}$ were present (e.g., $\mathrm{Cl}_{2}$; Oum et al., 1998), but photolysis of $\mathrm{ClNO}_{2}$ dominated (Riedel et al., 2012). Formation of secondary $\mathrm{Cl}$ atoms is also possible. Based on measurements from CalNex, the secondary $\mathrm{Cl}$ source was determined to be approximately 
$23 \%$ of the calculated total $\mathrm{Cl}$ production, and was more significant in late morning and early afternoon (Fig. 5a). Although the production of secondary $\mathrm{Cl}$ was not included in our model simulations, this source is small relative to the primary $\mathrm{Cl}$ source. The maximum $\mathrm{Cl}$ concentration calculated during CalNex was $8.7 \times 10^{3}$ atoms $\mathrm{cm}^{-3}$ and the average daytime concentration was $2.3 \times 10^{3}$ atoms $\mathrm{cm}^{-3}$. This calculation may slightly underestimate the $\mathrm{Cl}$ concentration, since minor primary sources have not been included. The lower-limit estimate for CalNex is of the same order as calculated by Knipping and Dabdub (2003) for Los Angeles, but substantially lower than calculated for Houston, Texas (mean of $7.6 \times 10^{4}$ atoms $\mathrm{cm}^{-3}$; Riemer et al., 2008). A minimum $[\mathrm{OH}]$ to $[\mathrm{Cl}]$ ratio of 109 was calculated at approximately 08:00 PDT coincident in time with the maximum $\mathrm{Cl}$ concentration (Fig. 5b). The sensitivity of VOC tracer ratios determined above suggests a sustained $[\mathrm{OH}]$ to $[\mathrm{Cl}]$ ratio of less than 200 is needed to detect $\mathrm{Cl}$ oxidation. At the Los Angeles ground site during CalNex, calculated $[\mathrm{OH}]$ to $[\mathrm{Cl}] \mathrm{ra}-$ tios are below 200 for approximately two hours beginning at 07:00 PDT. Thus, VOC tracer ratios, which are sensitive to radical concentration but not their primary sources, would show at best marginal evidence for $\mathrm{Cl}$ oxidation, and only over a short period during early morning, despite the relatively much larger contribution of $\mathrm{ClNO}_{2}$ photolysis as a primary radical source operative during that time.

Using the MCM modeling described in Sect. 2.3, we calculated the VOC tracer ratio evolutions for a simplified Los Angeles case during CalNex (Condition Set 3). These can be compared with measured VOC ratios assuming the air masses measured at the Pasadena site had a common history. The model does not attempt to replicate the complex meteorology or emissions within the Los Angeles Basin, but is instead used to assess the sensitivity of a more realistic VOC and radical precursor mixture to $\mathrm{Cl}$ reactions. The influence of $\mathrm{Cl}$ was tested with the inclusion of $\mathrm{ClNO}_{2}$ photolyzing to form either $\mathrm{Cl}$ or $\mathrm{OH}$. Results of the simulations are shown in Fig. 6. In the simulation including $\mathrm{Cl}$, there is an early-morning deviation from the $\mathrm{OH}$ oxidation consistent with the $[\mathrm{OH}]$ to $[\mathrm{Cl}]$ ratios presented in Fig. 5b. Following the loss of $\mathrm{ClNO}_{2}$ by photolysis, oxidation follows a line parallel to the $\mathrm{OH}$ oxidation line, indicating that $\mathrm{OH}$ is the dominant oxidizer for the remainder of the day. As expected, VOC tracer ratios in the simulation producing $\mathrm{OH}$ from the photolysis of $\mathrm{ClNO}_{2}$ are consistent with oxidation entirely by $\mathrm{OH}$. The predicted difference in $\ln ([i$-butane $] /[n-$ butane]) between $\mathrm{ClNO}_{2}$ reacting to form $\mathrm{OH}$ and $\mathrm{Cl}$ is less than 0.02. This difference is impossible to detect given the data scatter of approximately 0.5 in VOC tracer ratio measurements (Fig. 2a). As discussed above, sustained $[\mathrm{OH}]$ to [Cl] ratios of less than 200 are needed to detect the role of $\mathrm{Cl}$ using this method. Over the shorter timescale of high $\mathrm{Cl}$ concentrations observed during $\mathrm{CalNex}$, the $[\mathrm{OH}]$ to $[\mathrm{Cl}]$ ratio was not low enough to overcome both the uncertainty in the measurements and the variability observed in Los An-
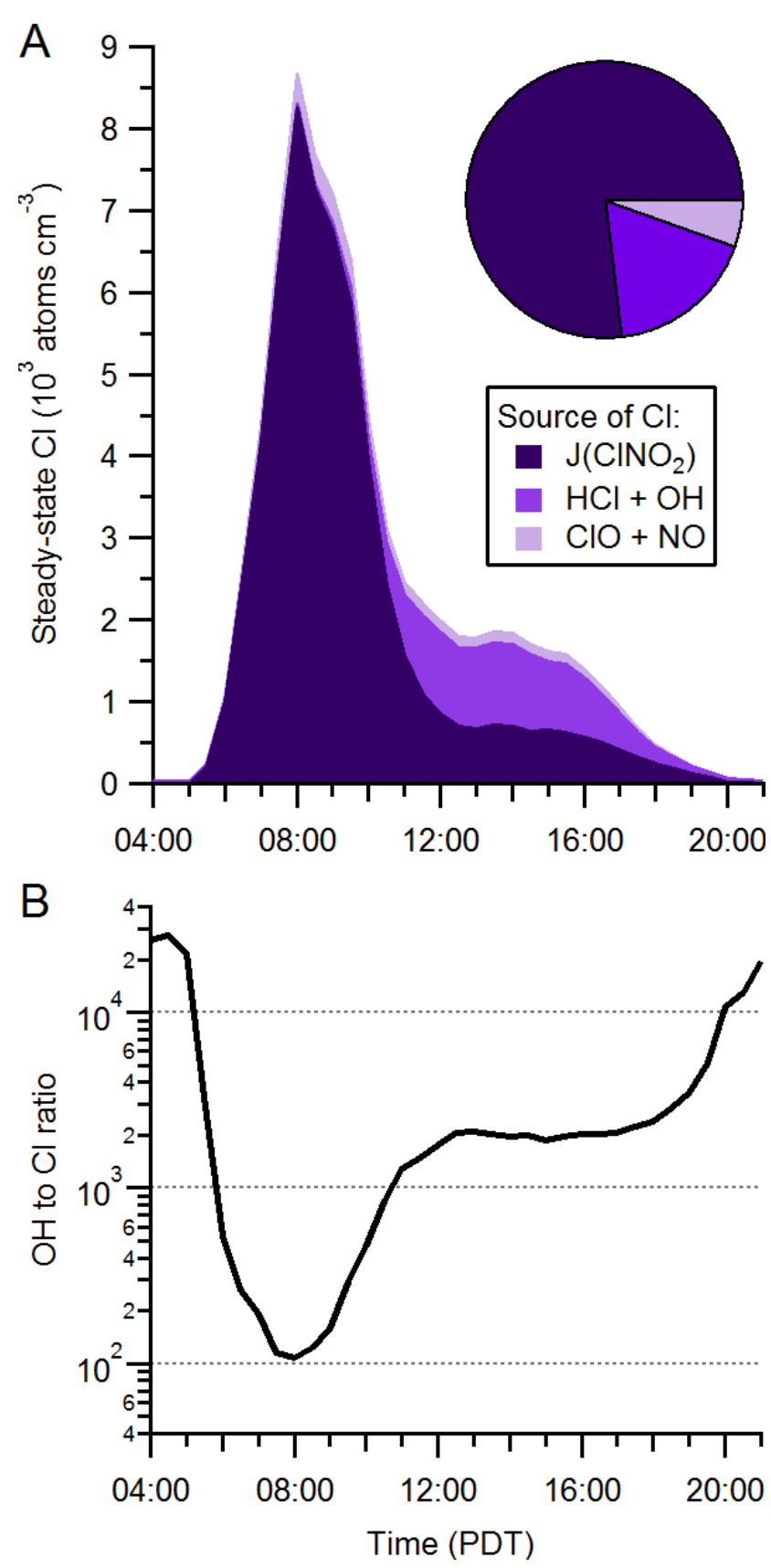

Fig. 5. (A) Calculated diurnal $\mathrm{Cl}$ concentration using measurements from the Pasadena ground site during CalNex; and (B) calculated $[\mathrm{OH}]$ to $[\mathrm{Cl}]$ ratio using measured $\mathrm{OH}$ concentrations from the Pasadena ground site during CalNex and calculated $\mathrm{Cl}$ concentrations.

geles for the most commonly used set of tracers ( $n$-butane, $i$-butane, and propane).

Incorporation of faster-reacting compounds into VOC tracer ratios can provide a more sensitive measure of the influence of $\mathrm{Cl}$. The toluene, $n$-hexane, and acetylene tracer ratios provide a more sensitive indicator of $\mathrm{Cl}$ oxidation. The ratio of [toluene] to [ $n$-hexane] (Fig. 2b, c), having different 


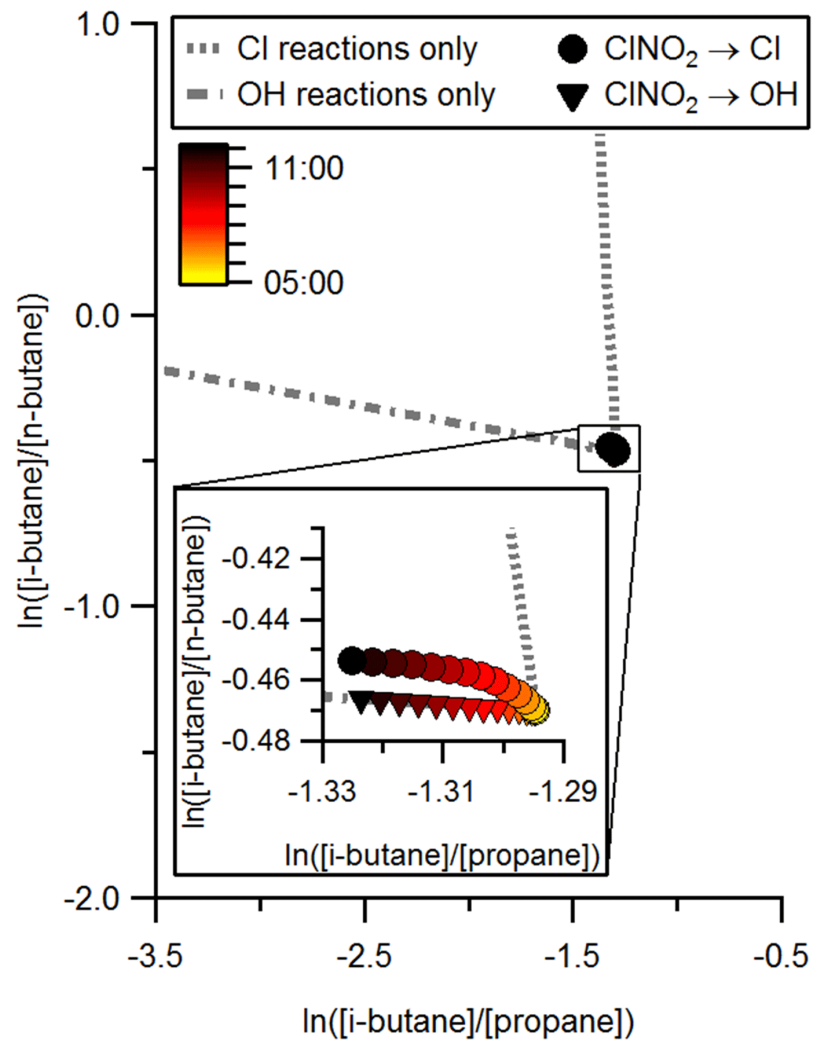

Fig. 6. MCM-calculated VOC tracer ratio evolution ( $i$-butane, $n$ butane, and propane) using Pasadena pre-sunrise measured concentrations of radical precursors and VOCs (Condition Set 3a), then changing the photolysis of $\mathrm{ClNO}_{2}$ to produce $\mathrm{OH}$ instead of $\mathrm{Cl}$ (Condition Set 3b). Scale is identical to that in Fig. 2a and expanded in the inset.

$\mathrm{Cl}$ but similar $\mathrm{OH}$ rate coefficients, is more than four times as sensitive to $\mathrm{Cl}$ as the ratio of [ $n$-butane] to [ $i$-butane] ratio (Fig. 2a) primarily considered above. However, the evolution of the toluene, $n$-hexane, and acetylene ratios considering all data (Fig. 2b) and the morning of 3 June (Fig. 2c) also reveals no indication of $\mathrm{Cl}$ oxidation. Results of Condition Set 3a indicate that uncertainty and variability in these ratios must be less than 0.06 to be detected, which is far less than the typical observed variability of 0.5 (Fig. $2 b, c$ ).

\subsection{Differences Between $\mathrm{Cl}$ and $\mathrm{OH}$ radicals}

Three key differences between the reactivity of $\mathrm{Cl}$ atoms and $\mathrm{OH}$ radicals affect tropospheric oxidation in Los Angeles. First, the reactivity of $\mathrm{Cl}$ with Los Angeles atmospheric composition is over an order of magnitude larger than that of $\mathrm{OH}$, leading to faster reaction of $\mathrm{Cl}$ with VOCs, and a shorter radical lifetime and smaller abundances. Second, the single largest contributor to $\mathrm{OH}$ loss (30\% of daytime integrated reactivity) is the radical sink reaction with $\mathrm{NO}_{2}$ to form nitric acid. This reaction is chain terminating, leading to permanent loss of $\mathrm{OH}$, such that only $\sim 70 \%$ of primary $\mathrm{OH}$ would par- ticipate in oxidation cycles that lead to radical propagation. Reactivity of $\mathrm{Cl}$, on the other hand, is due almost entirely to reactions that lead to radical recycling through oxidized VOCs. Although $\mathrm{Cl}$ also reacts with $\mathrm{NO}_{2}$ (accounting for $5 \%$ of total $\mathrm{Cl}$ reactivity), the reaction regenerates $\mathrm{ClNO}_{2}$ or its isomers, which simply returns the $\mathrm{Cl}$ to the radical pool through subsequent photolysis. Chain termination for $\mathrm{Cl}$ is possible through reaction with $\mathrm{O}_{3}$ (Reaction R7), which has the potential to form $\mathrm{HOCl}$ (Reaction R8a) if the resulting $\mathrm{ClO}$ does not react primarily with $\mathrm{NO}$ to regenerate $\mathrm{Cl}$ (Reaction R8b):

$$
\begin{aligned}
& \mathrm{Cl}+\mathrm{O}_{3} \rightarrow \mathrm{ClO}+\mathrm{O}_{2}, \\
& \mathrm{ClO}+\mathrm{HO}_{2} \rightarrow \mathrm{HOCl}+\mathrm{O}_{2}, \\
& \mathrm{ClO}+\mathrm{NO} \rightarrow \mathrm{Cl}+\mathrm{NO}_{2} .
\end{aligned}
$$

Reactions of $\mathrm{Cl}$ with $\mathrm{OH}$ also form $\mathrm{HOCl}$, but this is a negligible loss process for either radical:

$$
\mathrm{Cl}+\mathrm{OH} \rightarrow \mathrm{HOCl} \text {. }
$$

The chemistry of $\mathrm{HOCl}$ is complex, and likely leads to further radical recycling through its heterogeneous uptake. Even if $\mathrm{HOCl}$ production were to be regarded as a $\mathrm{Cl}$ loss, we calculate that formation of $\mathrm{HOCl}$ through Reactions (R8a) and (R7) accounts for less than a $1 \times 10^{-6}$ fraction of the total $\mathrm{Cl}$ loss in Los Angeles. We note that in lower VOC, lower $\mathrm{NO}_{\mathrm{x}}$ environments, such as remote ocean areas, $\mathrm{HOCl}$ production can be a significant fraction of total $\mathrm{Cl}$ loss (Lawler et al., 2009). Lastly, $\mathrm{Cl}$ reacts rapidly with species, such as alkanes, that are relatively unreactive with $\mathrm{OH}$. These differences suggest that primary $\mathrm{Cl}$ has impacts on tropospheric oxidation that cannot be assessed by a simple radical budget. Modeling studies have suggested the inclusion of $\mathrm{Cl}$ oxidation leads to increased production of $\mathrm{O}_{3}$ in coastal urban areas, including Los Angeles (Knipping and Dabdub, 2003; Osthoff et al., 2008). Further study is required to fully assess the impacts of $\mathrm{Cl}$ on VOC oxidation, radical generation and propagation, and $\mathrm{O}_{3}$ formation in light of recent fieldwork showing a large $\mathrm{Cl}$ atom source through formation and photolysis of $\mathrm{ClNO}_{2}$.

\section{Conclusions}

Previous studies have shown that $\mathrm{Cl}$ radicals play a significant role in Los Angeles photochemistry (Young et al., 2012; Mielke et al., 2013). Here we investigate why the evolution of VOC ratios in Los Angeles show no indication that these $\mathrm{Cl}$ radicals play a significant role in their oxidation (Figs. 1,2). Box modeling based upon the MCM indicates that VOC ratios do evolve as expected (Fig. 3) when the relative amounts 
of $\mathrm{Cl}$ and $\mathrm{OH}$ are artificially held at fixed ratios. However, even when the model is constrained so that the only primary radical source is photolysis of $\mathrm{ClNO}_{2}$ producing $\mathrm{Cl}$ (i.e., primary production of $\mathrm{OH}$ radicals from all sources are turned off), the VOCs evolve similarly to that expected for $\mathrm{OH}$ oxidation (Fig. 4a) over a range of $\mathrm{NO}_{\mathrm{x}}$ concentrations. The reason for this behavior is that VOC oxidation by the secondary $\mathrm{OH}$ produced from $\mathrm{Cl}$ oxidation of VOCs in the presence of $\mathrm{NO}_{\mathrm{x}}$ obscures the impact of $\mathrm{Cl}$ as a primary radical on the VOC ratios. Thus, although $\mathrm{Cl}$ may initiate oxidation cycles in Los Angeles, its influence is not apparent in the time evolution of measured ambient VOC ratios. These ratios are expected to show $\mathrm{Cl}$ oxidation signatures only below a sustained $\mathrm{OH}$ to $\mathrm{Cl}$ ratio of approximately 200 . However, since $\mathrm{ClNO}_{2}$ photolysis is a strong radical source only for a few hours in the early morning, $\mathrm{Cl}$ concentrations of this magnitude are not sustained long enough to impact the VOCs used in these VOC tracer ratios.

These results indicate that VOC tracer ratios do accurately reflect the relative oxidation of VOCs by the $\mathrm{Cl}$ and $\mathrm{OH}$ radicals present in the atmosphere, and when properly interpreted with appropriate consideration of the confounding effects of mixing (cf. Parrish et al., 2007), do provide useful indirect determinations of the average ratio of $\mathrm{Cl}$ to $\mathrm{OH}$ concentrations. However, in moderate- and high- $\mathrm{NO}_{\mathrm{x}}$ urban environments, the ratio of the radical concentrations do not provide an accurate indication of the relative impacts of the primary sources of the $\mathrm{Cl}$ and $\mathrm{OH}$ radicals, and it is these primary sources that drive urban photochemistry.

Any method that relies upon the ratio of $\mathrm{Cl}$ to $\mathrm{OH}$ concentrations to gauge the relative impacts of $\mathrm{Cl}$ and $\mathrm{OH}$ radicals may be biased without careful consideration of the impact of secondary radical formation. Both $\mathrm{Cl}$ atoms and $\mathrm{OH}$ radicals form secondary radicals through radical chain reactions, but these radicals are almost exclusively $\mathrm{OH}$ rather than $\mathrm{Cl}$. This secondary $\mathrm{OH}$ formation can then (depending upon $\mathrm{NO}_{\mathrm{X}}$ concentration) greatly enhance the $\mathrm{OH}$ concentration over the $\mathrm{Cl}$ concentration compared to that produced from the primary radical sources. Derivation of the average ratio of $[\mathrm{Cl}]$ to $[\mathrm{OH}]$ from analysis of measurements of $\mathrm{Cl}$ atom-isoprene addition products (such as reported by Riemer et al., 2008) suffers from the same potential bias as analysis of VOC ratios for exactly the same reason - secondary production of $\mathrm{OH}$ by $\mathrm{Cl}$. Interpretation of model results (e.g., Knipping and Dabdub, 2003) based upon calculated $\mathrm{Cl}$ to $\mathrm{OH}$ ratios will likewise be complicated by secondary radical production. To accurately gauge the relative impacts of $\mathrm{Cl}$ and $\mathrm{OH}$ in moderate- and high- $\mathrm{NO}_{\mathrm{x}}$ environments requires a time-integrated analysis of the primary radical production of both $\mathrm{Cl}$ and $\mathrm{OH}$ radicals.

Differences in radical chemistry also affect the relative impacts of $\mathrm{Cl}$ and $\mathrm{OH}$ formed in the primary formation processes. The Los Angeles atmospheric composition during CalNex was more than an order of magnitude more reactive with $\mathrm{Cl}$ than with $\mathrm{OH}$ (Fig. 7) and $\mathrm{Cl}$ reacts more rapidly

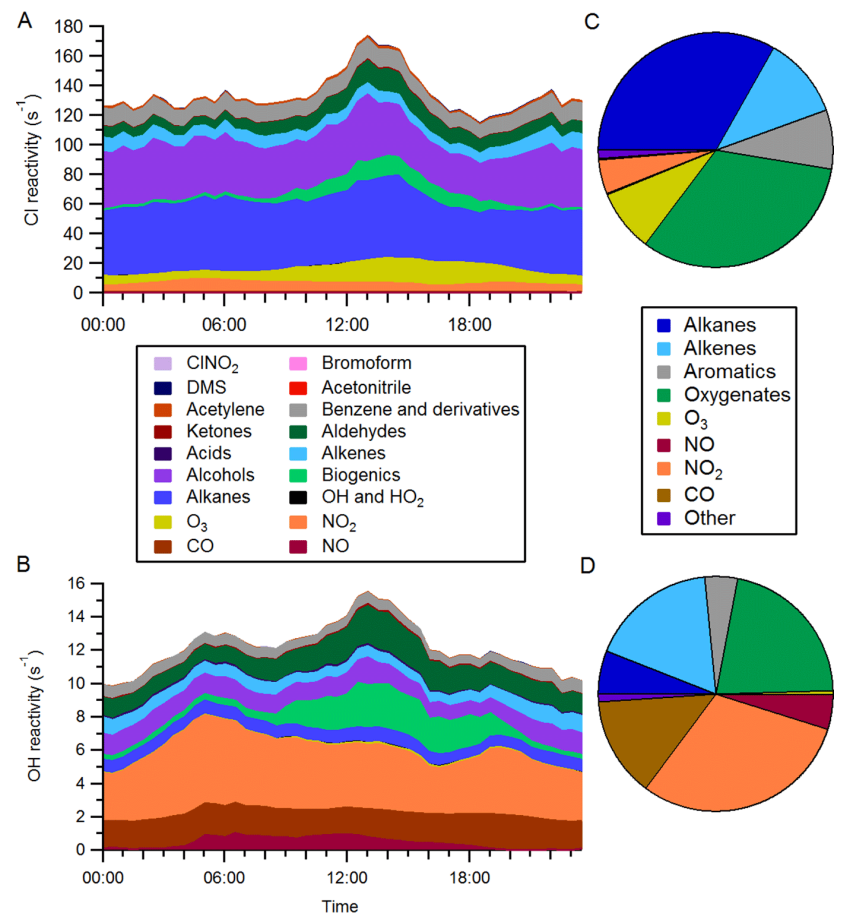

Fig. 7. Reactivity averaged over a diurnal cycle for (A) $\mathrm{Cl}$ and (B) $\mathrm{OH}$; Pie charts showing relative contributions to reactivity during daylight hours for (C) $\mathrm{Cl}$ and (D) $\mathrm{OH}$ calculated from measurements made in Pasadena during the CalNex campaign.

with some VOC species that are long-lived with respect to $\mathrm{OH}$ oxidation. $\mathrm{Cl}$ also more efficiently forms secondary radicals than $\mathrm{OH}$, since a significant fraction of $\mathrm{OH}$, but not $\mathrm{Cl}$, is lost to a chain termination reaction with $\mathrm{NO}_{2}$. All of these differences between the behavior of $\mathrm{Cl}$ and $\mathrm{OH}$ indicate that their contributions to tropospheric oxidation are not accurately captured through simple radical counting. The different effects of $\mathrm{Cl}$ and $\mathrm{OH}$ on tropospheric oxidation and ozone production should be explored quantitatively.

\section{Supplementary material related to this article is available online at http://www.atmos-chem-phys.net/14/ 3427/2014/acp-14-3427-2014-supplement.pdf.}

Acknowledgements. J. Stutz thanks J. de Gouw, J.-L. Jimenez, J. Seinfeld, and J. Suratt for co-organizing the CalNex site in Pasadena. The California Air Resources Board (CARB) and the California Institute of Technology are thanked for funding the site. We acknowledge financial support for the field measurements from CARB, the NOAA Air Quality and NOAA Climate Research; and C. J. Young thanks the Natural Sciences and Engineering Research Council of Canada for a postdoctoral fellowship.

Edited by: A. Hofzumahaus 


\section{References}

Allan, W., Lowe, D. C., and Cainey, J. M.: Active chlorine in the remote marine boundary layer: Modeling anomalous measurements of $\delta^{13} \mathrm{C}$ in methane, Geophys. Res. Lett., 28, 3239-3242, 2001.

Allan, W., Struthers, H., and Lowe, D. C.: Methane carbon isotope effects caused by atomic chlorine int he marine boundary layer: Global model results compared with Southern hemisphere measurements, J. Geophys. Res., 112, D04306, doi:10.1029/2006JD007369, 2007.

Archibald, A. T., Levine, J. G., Abraham, N. L., Cooke, M. C., Edwards, P. M., Heard, D. E., Jenkin, M. E., Karunaharan, A., Pike, R. C., Monks, P. S., Shallcross, D. E., Telford, P. J., Whalley, L. K., and Pyle, J. A.: Impacts of HOx regeneration and recycling in the oxidation of isoprene: Consequences for the composition of past, present and future atmospheres, Geophys. Res. Lett., 38, L05804, doi:10.1029/2010GL046520, 2011.

Atkinson, R., Baulch, D. L., Cox, R. A., Crowley, J. N., Hampson, R. F., Hynes, R. G., Jenkin, M. E., Rossi, M. J., Troe, J., and IUPAC Subcommittee: Evaluated kinetic and photochemical data for atmospheric chemistry: Volume II - gas phase reactions of organic species, Atmos. Chem. Phys., 6, 3625-4055, doi:10.5194/acp-6-3625-2006, 2006.

Atkinson, R., Baulch, D. L., Cox, R. A., Crowley, J. N., Hampson, R. F., Hynes, R. G., Jenkin, M. E., Rossi, M. J., and Troe, J.: Evaluated kinetic and photochemical data for atmospheric chemistry: Volume III - gas phase reactions of inorganic halogens, Atmos. Chem. Phys., 7, 981-1191, doi:10.5194/acp-7-981-2007, 2007.

Borbon, A., Gilman, J. B., Kuster, W. C., Grand, N., Chevaillier, S., Colomb, A., Dolgorouky, C., Gros, V., Lopez, M., SardaEsteve, R., Holloway, J. S., Stutz, J., Petetin, H., McKeen, S. A., Beekmann, M., Warneke, C., Parrish, D. D., and de Gouw, J. A.: Emission ratios of anthropogenic volatile organic compounds in northern mid-latitude megacities: Observations versus emission inventories in Los Angeles and Paris, J. Geophys. Res., 118, 117, doi:10.1002/jgrd.50059, 2013.

Boronska, K., Jimack, P., Pilling, M., Rickard, A., Moreno, M. V., Waller, D., and Young, J. C.: AtChem on-line project, https:// atchem.leeds.ac.uk (last access: 14 March 2013).

Chang, S. and Allen, D. T.: Atmospheric chlorine chemistry in Southeast Texas: Impacts on ozone formation and control, Environ. Sci. Technol., 40, 251-262, 2006.

Colman, J. J., Swanson, A. L., Meinardi, S., Sive, B. C., Blake, D. R., and Rowland, F. S.: Description of the analysis of a wide range of volatile organic compounds in whole air samples collected during PEM-Tropics A and B, Anal. Chem., 73, 37233731, 2001.

Dusanter, S., Vimal, D., Stevens, P. S., Volkamer, R., and Molina, L. T.: Measurements of $\mathrm{OH}$ and $\mathrm{HO}_{2}$ concentrations during the MCMA-2006 field campaign - Part 1: Deployment of the Indiana University laser-induced fluorescence instrument, Atmos. Chem. Phys., 9, 1665-1685, doi:10.5194/acp-9-1665-2009, 2009.

Erickson, D. J., Seuzaret, C., Keene, W. C., and Gong, S. L.: A general circulation model based calculation of $\mathrm{HCl}$ and $\mathrm{ClNO}_{2}, \mathrm{~J}$. Geophys. Res., 104, 8347-8372, doi:10.1029/98JD01384, 1999.

Gerbig, C., Schmitgen, S., Kley, D., Volz-Thomas, A., Dewey, K., and Haaks, D.: An improved fast-response vacuum-UV resonance fluorescence CO instrument, J. Geophys. Res., 104, 16991704, doi:10.1029/1998JD100031, 1999.
Ghosh, B., Papanastasiou, D. K., Talukdar, R. K., Roberts, J. M., and Burkholder, J. B.: Nitryl chloride $\left(\mathrm{ClNO}_{2}\right)$ : UV/Vis absorption spectrum between 210 and $296 \mathrm{~K}$ and $\mathrm{O}\left({ }^{3} \mathrm{P}\right)$ quantum yield at 193 and $248 \mathrm{~nm}$, J. Phys. Chem. A, 1169, 5796-5805, 2011.

Gilman, J. B., Burkhart, J. F., Lerner, B. M., Williams, E. J., Kuster, W. C., Goldan, P. D., Murphy, P. C., Warneke, C., Fowler, C., Montzka, S. A., Miller, B. R., Miller, L., Oltmans, S. J., Ryerson, T. B., Cooper, O. R., Stohl, A., and de Gouw, J. A.: Ozone variability and halogen oxidation within the Arctic and sub-Arctic springtime boundary layer, Atmos. Chem. Phys., 10, 10223-10236, doi:10.5194/acp-10-10223-2010, 2010.

Gorham, K. A., Blake, N. J., VanCuren, R. A., Fuelberg, H. E., Meinardi, S., and Blake, D. R.: Seasonal and diurnal measurements of carbon monoxide and nonmethane hydrocarbons at Mt. Wilson, California: Indirect evidence of atomic $\mathrm{Cl}$ in the Los Angeles basin, Atmos. Environ., 44, 2271-2279, 2010.

Jenkin, M. E., Saunders, S. M., and Piling, M. J.: The tropospheric degradation of volatile organic compounds: A protocol for mechanism development, Atmos. Environ., 31, 81-104, 1997.

Jenkin, M. E., Saunders, S. M., Wagner, V., and Pilling, M. J.: Protocol for the development of the Master Chemical Mechanism, MCM v3 (Part B): tropospheric degradation of aromatic volatile organic compounds, Atmos. Chem. Phys., 3, 181-193, doi:10.5194/acp-3-181-2003, 2003.

Jobson, B. T., Niki, H., Yokouchi, Y., Bottenheim, J., Hopper, F., and Leaitch, R.: Measurements of $\mathrm{C}_{2}-\mathrm{C}_{6}$ hydrocarbons during the Polar Sunrise 1992 experiment: Evidence for $\mathrm{Cl}$ atom and $\mathrm{Br}$ atom chemistry, J. Geophys. Res., 99, 25355-25368, 1994.

Kaiser, E. W. and Wallington, T. J.: Rate constant of the reaction of chlorine atoms with methanol over the temperature range 291475K, Int. J. Chem. Kinet., 42, 113-116, 2010.

Keene, W. C., Khalil, M. A. K., Erickson, D. J., McCulloch, A., Graedel, T. E., Lobert, J. M., Aucott, M. L., Gong, S. L., Harper, D. B., Kleiman, G., Midgley, P., Moore, R. M., Seuzaret, C., Sturges, W. T., Benkovitz, C. M., Koropalov, V., Barrie, L. A., and $\mathrm{Li}$, Y. F.: Composite global emissions of reactive chlorine from anthropogenic and natural sources: Reactive chlorine emissions inventory, J. Geophys. Res., 104, 8429-8440, 1999.

Knipping, E. M. and Dabdub, D.: Impact of chlorine emissions from sea-salt aerosol on coastal urban ozone, Environ. Sci. Technol., 37, 275-284, 2003.

Knipping, E. M., Lakin, M. J., Forster, K. L., Jungwirth, P., Tobias, D. J., Gerber, R. B., Dabdub, D., and Finlayson-Pitts, B. J.: Experiments and simulations of ion-enhanced interfacial chemistry on aqueous $\mathrm{NaCl}$ aerosols, Science, 288, 301-306, 2000.

Lawler, M. J., Finley, B. D., Keene, W. C., Pszenny, A. A. P., Read, K. A., von Glasow, R., and Saltzman, E. S.: Pollutionenhanced reactive chlorine chemistry in the eastern tropical Atlantic boundary layer, Geophys. Res. Lett., 36, L08810, doi:10.1029/2008GL036666, 2009.

Lawler, M. J., Sander, R., Carpenter, L. J., Lee, J. D., von Glasow, R., Sommariva, R., and Saltzman, E. S.: $\mathrm{HOCl}$ and $\mathrm{Cl}_{2}$ observations in marine air, Atmos. Chem. Phys., 11, 7617-7628, doi:10.5194/acp-11-7617-2011, 2011.

Lelieveld, J., Butler, T. M., Crowley, J. N., Dillon, T. J., Fischer, H., Ganzeveld, L., Harder, H., Lawrence, M. G., Martinez, M., Taraborrelli, D., and Williams, J.: Atmospheric oxidation capacity sustained by a tropical forest, Nature, 452, 737-740, 2008. 
Mielke, L. H., Furgeson, A., and Osthoff, H. D.: Observation of $\mathrm{ClNO}_{2}$ in a mid-continental urban environment, Environ. Sci. Technol., 45, 8889-8896, 2011.

Mielke, L. H., Stutz, J., Tsai, C., Hurlock, S., Roberts, J. M., Veres, P. R., Froyd, K., Hayes, P., Cubison, M., Jimenez, J. L., Washenfelder, R. A., Young, C. J., Gilman, J. B., de Gouw, J., Flynn, J., Grossberg, N., Lefer, B., Liu, J., Weber, R., and Osthoff, H. D.: Heterogeneous formation of nitryl chloride and its role as a nocturnal $\mathrm{NO}_{\mathrm{x}}$ reservoir species during CalNex-LA 2010, J. Geophys. Res., 118, 10638-10652, doi:10.1002/jgrd.50783, 2013.

Nordmeyer, T., Wang, W., Ragains, M. L., Finlayson-Pitts, B. J., Spicer, C. W., and Plastridge, R. A.: Unique products of the reaction of isoprene with atomic chlorine: Potential markers of chlorine atom chemistry, Geophys. Res. Lett., 24, 1615-1618, 1997.

Osthoff, H. D., Roberts, J. M., Ravishankara, A. R., Williams, E. J., Lerner, B. M., Sommariva, R., Bates, T. S., Coffman, D., Quinn, P. K., Dibb, J. E., Stark, H., Burkholder, J. B., Talukdar, R. K., Meagher, J., Fehsenfeld, F. C., and Brown, S. S.: High levels of nitryl chloride in the polluted subtropical marine boundary layer, Nat. Geosci., 1, 324-328, 2008.

Oum, K. W., Lakin, M. J., De Haan, D. O., Brauers, T., and Finlayson-Pitts, B. J.: Formation of molecular chlorine from the photolysis of ozone and aqueous sea-salt particles, Science, 279, 74-77, 1998.

Parrish, D. D., Stohl, A., Forster, C., Atlas, E. L., Blake, D. R., Goldan, P. D., Kuster, W. C., and de Gouw, J. A.: Effects of mixing on evolution of hydrocarbon ratios in the troposphere, J. Geophys. Res., 112, D10S34, doi:10.1029/2006JD007583, 2007.

Peischl, J., Ryerson, T. B., Brioude, J., Aikin, K. C., Andrews, A. E., Atlas, E., Blake, D., Daube, B. C., de Gouw, J. A., Dlugokencky, E., Frost, G. J., Gentner, D. R., Gilman, J. B., Goldstein, A. H., Harley, R. A., Holloway, J. S., Kofler, J., Kuster, W. C., Lang, P. M., Novelli, P. C., Santoni, G. W., Trainer, M., Wofsy, S. C., and Parrish, D. D.: Quantifying sources of methane using light alkanes in the Los Angeles basin, California, J. Geophys. Res., 118, 4974-4990, doi:10.1002/jgrd.50413, 2013.

Platt, U., Allan, W., and Lowe, D.: Hemispheric average $\mathrm{Cl}$ atom concentration from ${ }^{13} \mathrm{C} /{ }^{12} \mathrm{C}$ ratios in atmospheric methane, Atmos. Chem. Phys., 4, 2393-2399, doi:10.5194/acp-4-2393-2004, 2004.

Pzsenny, A. A. P., Fischer, E. V., Russo, R. S., Sive, B. C., and Varner, R. K.: Estimates of $\mathrm{Cl}$ atom concentrations and hydrocarbon kinetic reactivity in surface air at Appledore Island, Maine (USA), during International Consortium for Atmospheric Research on Transport and Transformation/Chemistry of Halogens at the Isles of Shoals, J. Geophys. Res., 112, D10S13, doi:10.1029/2006JD007725, 2007.

Ramacher, B., Rudolph, J., and Koppmann, R.: Hydrocarbon measurements during tropospheric ozone depletion events: Evidence for halogen atom chemistry, J. Geophys. Res., 104, 3633-3653, 1999.

Riedel, T. P., Bertram, T. H., Crisp, T. A., Williams, E. J., Lerner, B. M., Vlasenko, A., Li, S.-M., Gilman, J., de Gouw, J., Bon, D. M., Wagner, N. L., Brown, S. S., and Thornton, J. A.: Nitryl chloride and molecular chlorine in the coastal marine boundary layer, Environ. Sci. Technol., 46, 10463-10470, 2012.

Riemer, D. D., Apel, E. C., Orlando, J. J., Tyndall, G. S., Brune, W. H., Williams, E. J., Lonneman, W. A., and Neece, J. D.: Unique isoprene oxidation products demonstrate chlorine atom chem- istry occurs in the Houston, Texas urban area, J. Atmos. Chem., 61, 227-242, 2008.

Rudolph, J., Ramacher, B., Plass-Dulmer, C., Muller, K.-P., and Koppmann, R.: The indirect determination of chlorine atom concentration in the troposphere from changes in the patterns of nonmethane hydrocarbons, Tellus B, 49, 592-601, 1997.

Ryerson, T. B., Andrews, A. E., Angevine, W. M., Bates, T. S., Brock, C. A., Cairns, B., Cohen, R. C., Cooper, O. R., de Gouw, J. A., Fehsenfeld, F. C., Ferrare, R. A., Fischer, M. L., Flagan, R. C., Goldstein, A. H., Hair, J. W., Hardesty, R. M., Hostetler, C. A., Jimenez, J. L., Langford, A. O., McCauley, E., McKeen, S. A., Molina, L. T., Nenes, A., Oltmans, S. J., Parrish, D. D., Pederson, J. R., Pierce, R. B., Prather, K., Quinn, P. K., Seinfeld, J. H., Senff, C. J., Sorooshian, A., Stutz, J., Surratt, J. D., Trainer, M., Volkamer, R., Williams, E. J., and Wofsy, S. C.: The 2010 California Research at the Nexus of Air Quality and Climate Change (CalNex) field study, J. Geophys. Res., 118, 5830 5866, doi:10.1002/jgrd.50331, 2013.

Sander, S. P., Friedl, R. R., Abbatt, J. P. D., Barker, J. R., Burkholder, J. B., Golden, D. M., Kolb, C. E., Kurylo, M. J., Moortgat, G. K., Wine, P. H., Huie, R. E., and Orkin, V. L.: Chemical kinetics and phtoochemical data for use in atmospheric studies: Evaluation number 17, in JPL Publication 10-6, Jet Propulsion Laboratory, Pasadena, 2011.

Saunders, S. M., Jenkin, M. E., Derwent, R. G., and Pilling, M. J.: Protocol for the development of the Master Chemical Mechanism, MCM v3 (Part A): tropospheric degradation of nonaromatic volatile organic compounds, Atmos. Chem. Phys., 3, 161-180, doi:10.5194/acp-3-161-2003, 2003.

Shetter, R. E. and Muller, M.: Photolysis frequency measurements using actinic flux spectroradiometry during the PEM-Tropics mission: Instrumentation description and some results, J. Geophys. Res., 104, 5647-5661, 1999.

Singh, H. B., Thakur, A. N., Chen, Y. E., and Kanakidou, M.: Tetrachloroethylene as an indicator of low $\mathrm{Cl}$ atom concentrations in the troposphere, Geophys. Res. Lett., 23, 1529-1532, 1996.

Stutz, J., Ackermann, R., Fast, J. D., and Barrie, L.: Atmospheric reactive chlorine and bromine at the Great Salt Lake, Utah, Geophys. Res. Lett., 29, 1380, doi:10.1029/2002GL014812, 2002.

Taatjes, C. A., Christensen, L. K., Hurley, M. D., and Wallington, T. J.: Absolute and site-specific abstraction rate coefficients for reactions of $\mathrm{Cl}$ with $\mathrm{CH}_{3} \mathrm{CH}_{2} \mathrm{OH}, \mathrm{CH}_{3} \mathrm{CD}_{2} \mathrm{OH}$, and $\mathrm{CD}_{3} \mathrm{CH}_{2} \mathrm{OH}$ between 295 and $600 \mathrm{~K}$, J. Phys. Chem. A, 103, 9805-9814, 1999.

Tanaka, P. L., Riemer, D. D., Chang, S., Yarwood, G., McDonaldBuller, E. C., Apel, E. C., Orlando, J. J., Silva, P. J., Jimenez, J. L., Canagaratna, M. R., Neece, J. D., Mullins, C. B., and Allen, D. T.: Direct evidence for chlorine-enhanced urban ozone formation in Houston, Texas, Atmos. Environ., 37, 1393-1400, 2003.

Thornton, J. A., Kercher, J. P., Riedel, T. P., Wagner, N. L., Cozic, J., Holloway, J. S., Dube, W. P., Wolfe, G. M., Quinn, P. K., Middlebrook, A. M., Alexander, B., and Brown, S. S.: A large atomic chlorine source inferred from mid-continental reactive nitrogen chemistry, Nature, 464, 271-274, 2010.

Veres, P. R., Roberts, J. M., Cochran, A. K., Gilman, J. B., Kuster, W. C., Holloway, J. S., Graus, M., Flynn, J., Lefer, B., Warneke, C., and de Gouw, J.: Evidence of rapid production of organic acids in an urban air mass, Geophys. Res. Lett., 38, L17807, doi:10.1029/2011GL048420, 2011. 
Washenfelder, R. A., Young, C. J., Brown, S. S., Angevine, W. M., Atlas, E. L., Blake, D. R., Bon, D. M., Cubison, M. J., de Gouw, J. A., Dusanter, S., Flynn, J., Gilman, J. B., Graus, M., Griffith, S., Grossberg, N., Hayes, P. L., Jimenez, J. L., Kuster, W. C., Lefer, B. L., Pollack, I. B., Ryerson, T. B., Stark, H., Stevens, P. S., and Trainer, M. K.: The glyoxal budget and its contribution to organic aerosol for Los Angeles, California, during CalNex 2010, J. Geophys. Res., 116, D00V02, doi:10.1029/2011JD016314, 2011.

Wingenter, O. W., Kubo, M. K., Blake, N. J., Smith, T. W., Blake, D. R., and Rowland, F. S.: Hydrocarbon and halocarbon measurements as photochemical and dynamical indicators of atmospheric hydroxyl, atomic chlorine, and vertical mixing obtained during Lagrangian flights, J. Geophys. Res., 101, 4331-4340, 1996.

Wingenter, O. W., Blake, D. R., Blake, N. J., Sive, B. C., Rowland, F. S., Atlas, E., and Flocke, F.: Tropospheric hydroxyl and atomic chlorine concentrations, and mixing timescales determined from hydrocarbon and halocarbon measurements made over the Southern Ocean, J. Geophys. Res., 104, 21819-21828, 1999.

Wingenter, O. W., Sive, B. C., Blake, N. J., Blake, D. R., and Rowland, F. S.: Atomic chlorine concentrations derived from ethane and hydroxyl measurements over the equatorial Pacific Ocean: Implication for dimethyl sulfide and bromine monoxide, J. Geophys. Res., 110, D20308, doi:10.1029/2005JD005875, 2005.
Wong, K. W., Oh, H.-J., Lefer, B. L., Rappenglück, B., and Stutz, J.: Vertical profiles of nitrous acid in the nocturnal urban atmosphere of Houston, TX, Atmos. Chem. Phys., 11, 3595-3609, doi:10.5194/acp-11-3595-2011, 2011.

Yamanaka, T., Kawasaki, M., Wallington, T. J., Schneider, W. F., and Bruce, J.: Kinetics and mechanism of the gas phase reaction of chlorine atoms with i-propanol, Phys. Chem. Chem. Phys., 9, 4211-4217, 2007.

Yarwood, G., Peng, N., and Niki, H.: FTIR study of the mechanism of the $\mathrm{Cl}$ and $\mathrm{Br}$ atom initiated oxidation of acetylene, J. Phys. Chem., 95, 7330-7337, 1991.

Young, C. J., Washenfelder, R. A., Roberts, J. M., Mielke, L. H., Osthoff, H. D., Tsai, C., Pikelnaya, O., Stutz, J., Veres, P. R., Cochran, A. K., VandenBoer, T. C., Flynn, J., Grossberg, N., Haman, C. L., Lefer, B., Stark, H., Graus, M., de Gouw, J., Gilman, J. B., Kuster, W. C., and Brown, S. S.: Vertically resolved measurements of nighttime radical reservoirs in Los Angeles and their contribution to the urban radical budget, Environ. Sci. Technol., 46, 10965-10973, 2012.

Zhou, W., Zhai, Z., Wang, Z., and Wang, L.: Estimation of noctanol/water parition coefficients (KOW) of all PCB congeners by density functional theory, J. Mol. Struc.-Theochem., 755, 137-145, 2005. 